\title{
The Relationship between Student Science Teachers' Views on Nature of Science and Classroom Practice: Is There Any?
}

Constantina Stefanidou

National and Kapodistrian University of Athens

Greece

Constantine Skordoulis

National and Kapodistrian University of Athens

Greece

Christos Kechagias

National and Kapodistrian University of Athens

Greece

Received: August 25, 2018 Accepted: Oct. 12, 2018 Published: November 1, 2018

doi:10.5296/jse.v8i4.13720 URL: https://doi.org/10.5296/jse.v8i4.13720

\begin{abstract}
The present study investigated the relationship between student science teachers' views on Nature of Science and their views on the importance of teaching Nature of Science. It is a case study in which qualitative methods and descriptive statistics are used. The sample consisted of 23 student science teachers who attended a faculty course on Didactics of Physics and participated voluntarily. Preliminary findings showed a moderate relationship between students' views on Nature of Science issues and their classroom practice, particularly regarding "tenets" such as the tentative character of science and sociocultural milieu. When it comes to more epistemological issues, such as the difference between a theory and a law, then student teachers have considerable conceptual difficulties and they also find the particular "tenets" less important for a school science context.
\end{abstract}

Keywords: Nature of Science, Science Education, Attitude towards Nature of Science Teaching 


\section{Introduction}

In recent years there has been more and more interest in the Nature of Science (NOS) in the context of Science Education (SE). Education policy documents (OECD, 2009; AAAS, 1989, 2009, 2013) consider science literacy as a main goal of SE. Scientific literacy consists of acquiring science content knowledge as well as acquiring the NOS that includes the methods of science and its characteristics. Researchers in the field of SE (Hipkins et al., 2005, Lederman, 2006; Millar \& Osborne, 1998) and science standards (NGSS Lead States, 2013) emphasize the importance of the students' understanding on several aspects of NOS. The preamble to National Science Teachers Association (NSTA) (2000) position statement on NOS begins by asserting that "all those involved with science teaching and learning should have a common, accurate view of the nature of science." Their rationale is that if students comprehend how scientific knowledge has evolved, and how the historical, philosophical and technological context has influenced the development of science then they will gain a more extensive view of science and they will be more actively involved in the relevant cognitive processes.

The conceptualization of NOS that has been most widely used in science education research and practice is based on some general aspects of NOS (Lederman et al., 2002; McComas et al., 1998; Niaz, 2009; Osborne et al., 2003). This conceptualization will be referred to here as the "general aspects" conceptualization of NOS (Kampourakis, 2016, p. 667). According to this, there are some general aspects of NOS, which can be effectively taught in the context of science courses. These include aspects of the Nature of Scientific Knowledge (NOSK) as well as the inquiry methods and processes by which this knowledge is produced (Scientific Inquiry - SI). The aim of this conceptualization is not to cover all aspects of NOS but rather to address students' common preconceptions about NOS and to introduce them to the teaching and the learning of this topic. However, this conceptualization has been criticized as insufficient and misleading (Allchin, 2011; Duschl \& Grandy, 2013; Hodson, 2014; Irzik \& Nola, 2011; Matthews, 2012). These critics support a different conceptualization of NOS, with an emphasis on the differences among the various science disciplines and thus the (different) kinds of sciences. This is referred to as "family resemblance" conceptualization of NOS (Kampourakis, 2016, p. 667). The two conceptualizations are not considered as mutually exclusive but rather as continuous and complementary, also called "the general aspects" suggesting that they are the starting point for teaching and learning NOS (Kampourakis, 2016, p. 667)

During the last decades, extensive empirical research has been done related to students' views on NOS (Lederman, 1992; McComas et al., 1998). Students have various misconceptions about natural phenomena and their interpretations and as a result of that they also have corresponding misconceptions about the NOS. Such preconceptions, about what is science and how it works, originate from various resources, one of which is school science. Although many attempts have been made in the direction of curricula reform towards enhancing NOS teaching, the empirical research reveals a lot of difficulties regarding teaching practice. Moreover, teachers usually do not have adequate knowledge on NOS in order to design and conduct successful teaching sequences on NOS topics. Even worse, literature review shows 
that teachers usually have preconceptions about NOS as well (Stefanidou \& Skordoulis, 2017).

Empirical research regarding teachers' views on NOS goes back in 1950 (Anderson, 1950) revealing severe preconceptions. Miller's research confirmed teachers' conceptual difficulties regarding NOS and showed that in some aspects of science, students had a more informed point of view than their teachers (Miller, 1963). Carey and Strauss (1968) studied science teachers' views on NOS and found that they also had misconceptions, independently of their academic qualifications. Cawthron and Rowell (1978) revealed that science teachers usually have a naïve realistic stance toward science and its methods, while a few years later they showed that science teachers usually have an inductive and empirical view of how science works (Rowell \& Cawthron, 1982). Recent research reveal that pre-service and in-service science teachers are not informed about the cultural component of science (Brush, 1989; Stefanidou \& Skordoulis, 2014), while they adopt a positivistic view that permeates science curricula as a result of the influence of philosophical positivism (DeBoer, 1991). Science teachers' difficulty to perceive science philosophically (Stefanopoulou \& Kechagias, 2018) and their tendency to use a rather empiricist reasoning is also mentioned (Abd-El-Khalick \& Lederman, 2000).

Regarding the relationship between teachers' views on NOS and teaching practice, previous research has shown that teacher conceptions of the NOS do not necessarily influence classroom practice (Lederman, 1999). Lederman collected data of five biology teachers' conceptions on NOS and classroom practice. All teachers possessed informed understandings of NOS. During a full academic year, data were collected from questionnaires, structured and unstructured interviews, classroom observations, and instructional materials. Data were also collected on students' conceptions of NOS through questionnaires and interviews. The results of the investigation indicated that although the teachers possessed good understandings of NOS, classroom practice was not directly affected. Even in the classrooms that exhibited some similarity with teachers' understandings, students did not learn NOS because the teachers did not explicitly intend to teach NOS. Overall, the research was consistent with emerging findings about the relationship between teachers' understandings and classroom practice, as well as the research indicating the importance of explicit instructional attention to NOS.

There is emerging evidence that an explicit and reflective approach to the teaching of NOS is more effective than implicit approaches regarding students' conceptions of NOS (Lederman, 2006). However, in order for future teachers to be effective in teaching NOS issues, they should consider it as important; their opinion, on this matter, counts. The literature reveals that it is not enough for teachers to have informed views in order to be prepared and adequate to teach NOS. According to the above, a need arises to investigate a possible relationship between student science teachers' views on NOS and their views of whether it is necessary to teach NOS issues to schools or not. Their positive attitude towards explicitly teaching NOS at school could be encouraging and reflective in order to study further and improve their own knowledge about NOS issues. 


\section{Purpose of the study}

The present study investigated the relationship between student science teachers' views on NOS and their views on the importance of teaching NOS. The research questions are as follow:

a. What are student science teachers' views about NOS?

b. Do student science teachers feel that it is important to teach NOS in school?

c. Is there any relationship between the above?

\section{Research Procedure - Sample - Method}

The sample group consisted of 23 undergraduate student science teachers, 14 males and 9 females, who studied Physics in the Department of Physics in the University of Athens. This specific department offers no particular training to science education except for an elective subject that is offered to those who are interested in following a career as science teachers. All the 23 students participated in this specific elective course, namely Didactics of Science, which ran during the winter semester of 2017-2018. It was offered by the Department of Primary Education of University of Athens and lasted 13 weeks. The sample of the present study is convenient and limited. This is a parameter that classifies this research as a pilot and an exploratory one.

The course was organized in three parts: The first part consisted of lectures related to the term of scientific literacy and didactic models for teaching science. The second part was related to designing didactic material: teaching scenarios, activities, work sheets, etc. At that point students were asked to find a topic of their choice in order to design and develop a teaching proposal (scenario) based on Inquiry Based teaching strategies. During the third part of the course, students presented in the class their didactic proposals and submitted their written reports (scenarios). Due to the nature of the specific course, which was an introduction to the theory and practice of didactics of science, students didn't have the time to take any special training on NOS issues. However, they were familiar with NOS aspects through the explanations and examples given which were related to the term of scientific literacy. In other words, student science teachers were taught neither the "general aspects" approach nor the "family resemblance" approach of NOS, let alone how to teach it in the classroom.

Two questionnaires were used and observations were made. Specifically, the first questionnaire was about the views of the student teachers on NOS (VNOS-C) (Lederman et al., 2002) and it was completed after the course (Appendix). It consisted of 10 open-ended questions about NOS. Even though there are some disagreements among science educators, scientists, and philosophers regarding the appropriate views of the NOS, there is consensus in the science education community (Abd-El-Khalick \& Lederman, 2000). A coding scheme, based on informed views of NOS (Lederman et al., 2002), was used to code the VNOS-C data. Six categories of NOS views were delineated: (1) tentative (scientific knowledge is subject to change); (2) creative and imaginative (scientists utilize their creativity and imagination); (3) social and cultural (science is socially and culturally embedded); (4) theory laden (science is subjective); (5) inference (science is based on human inference); and (6) theory and law (the scientific differences between theories and laws) (Abd-El-Khalick \& 


\section{MInstitute Macrothink $_{\text {Int }}$}

Lederman, 2000). These six categories were examined in order to determine whether or not students possessed informed views for each NOS category.

The second questionnaire was about student science teachers' stance towards teaching NOS and to what extent they included in their didactic proposals teaching objectives related to NOS. This questionnaire was based on the corresponding questionnaire of Souter and Findlay (2008) that had derived from McComas and colleagues (1998). Students had to decide how important every aspect of NOS was, in order for that aspect of NOS to be included in their teaching (McComas et al., 1998), in a 4-point Likert scale: Very important, important, indifferent, and unnecessary. Moreover, for every aspect of NOS, they had to note whether they had included it in their teaching objectives or not. If student teachers had not included the specific NOS aspect in their lesson plan, they had to note whether it was by choice or by ignorance, if they lacked the knowledge how to do it. Regarding term papers, student teachers were asked to develop teaching material, particularly a 2-4-hour teaching scenario, related to a physics topic of their choice. They presented their work in class in fifteen minutes and the first author noted some remarks regarding the emphasis or lack of emphasis they had placed on NOS issues. An observation sheet was completed regarding how many teaching objectives related to NOS every student teacher had included and whether or not these objectives were taught through the proposed activities.

This study was a qualitative descriptive analysis where content analysis was used as a tool to monitor the student teachers' views on NOS. Hence, to quantify the findings and to present a clearer picture of the situation, descriptive statistics were used. The first and the third author focused on an inductive analysis and immersed themselves in the details of the open-ended data (VNOS - C Questionnaire) to get a sense of the whole and to find the themes reported here. To begin the analysis, two independent coders, the first and the third author, made judgments regarding student responses and coded them according to their view as naïve or informed. The agreement was about $90 \%$. Discussions about the two categories followed. Disagreements were resolved through discussions between scorers.

The second questionnaire was related with the student science teachers' stance towards teaching NOS and it was compared with the results of the observation sheet. Student teachers' stances towards teaching NOS were cross-checked by their responses in the questionnaire as well as the observations of the first author during the presentation of the term papers.

\section{Results}

\subsection{Student Science Teachers'Views on NOS}

The VNOS-C instrument was used to measure student science teachers' perspectives on the NOS. Table 1 provides samples of what authors coded as informed and naïve views of NOS from our participants. 
Table 1. Sample of student science teachers' views on NOS

\begin{tabular}{|c|c|c|}
\hline Aspect of NOS & Informed & Naïve \\
\hline Theories and Laws & $\begin{array}{l}\text { A scientific law describes, while a } \\
\text { theory explains. For example, } 2^{\text {nd }} \\
\text { Newton's Law, F=ma, either explains } \\
\text { what is a force, or how force causes } \\
\text { acceleration. }\end{array}$ & $\begin{array}{l}\text { Scientific theory is not } \\
\text { experimentally proved, } \\
\text { that's why it is a theory } \\
\text { and not a law. It may } \\
\text { change in the future, in } \\
\text { contrast to law that is } \\
\text { unchangeable. }\end{array}$ \\
\hline Tentative & $\begin{array}{l}\text { Scientific theories may change. } \\
\text { Human kind approaches the truth } \\
\text { though developing science. A theory } \\
\text { that today is revolutionary tomorrow } \\
\text { will be surpassed. For example, } \\
\text { Bohr's atomic theory is replaced by } \\
\text { the quantum mechanics. }\end{array}$ & $\begin{array}{l}\text { I don't believe that } \\
\text { theories change and this } \\
\text { is the reason physics is } \\
\text { such an important } \\
\text { science! The study of } \\
\text { theories is useless if they } \\
\text { are to change tomorrow! }\end{array}$ \\
\hline $\begin{array}{l}\text { Creative and } \\
\text { Imaginative }\end{array}$ & $\begin{array}{l}\text { Scientists use their imagination and } \\
\text { creativity in every step of their } \\
\text { research: during the mental design of } \\
\text { the experimental procedure in order } \\
\text { to control their hypothesis, after data } \\
\text { collection in order to interpret their } \\
\text { data, and also during the data } \\
\text { collection. While reasoning and } \\
\text { critical thinking is the foundation of } \\
\text { science, creativity is its railings. }\end{array}$ & - \\
\hline $\begin{array}{l}\text { Subjective and } \\
\text { Theory laden - } \\
\text { Distinction } \\
\text { between } \\
\text { observation and } \\
\text { inference }\end{array}$ & $\begin{array}{l}\text { Every scientist has his/her own } \\
\text { perspective towards nature, his/her } \\
\text { own cognitive lenses through which } \\
\text { he/she interprets the phenomena. } \\
\text { Every scientist has his/her own way } \\
\text { to explain phenomena, to analyze } \\
\text { data according to his/her scientific } \\
\text { and personal background in which } \\
\text { he/she was grown. That's why } \\
\text { sometimes the same set of data may } \\
\text { lead to different theories. }\end{array}$ & $\begin{array}{l}\text { The most important step } \\
\text { for a scientist is to have } \\
\text { the "right" data. Only then } \\
\text { he/she can think about an } \\
\text { explanation. Different } \\
\text { theories for the same set } \\
\text { of data, only means that } \\
\text { some scientists work in } \\
\text { the right way and some } \\
\text { others in the wrong way. } \\
\text { It is not possible for two } \\
\text { scientifically accepted } \\
\text { theories to co-exist based } \\
\text { on the same data. }\end{array}$ \\
\hline Social and Cultural & $\begin{array}{l}\text { Science should be universal and } \\
\text { impartial. However, its development }\end{array}$ & $\begin{array}{l}\text { I think that science is } \\
\text { universal. In the past, }\end{array}$ \\
\hline
\end{tabular}




\begin{tabular}{|l|l|l|}
\hline could not be influenced by the & science was censored but \\
prevailing social and political & nowadays, every single \\
conditions. For example, in an & scientist can express \\
authoritarian regime, that imposes & his/her ideas openly, \\
certain beliefs (e.g., dictatorship) & without social and \\
scientific development stays behind. & political interventions. \\
Moreover, nowadays, the only & \\
scientific subjects that are developed & \\
are those that are financed. For & \\
example, if there is demand for & \\
quantum computers, then this field & \\
will be developed and others, such as & \\
astrophysics, will be neglected. & \\
\hline
\end{tabular}

Table 2 provides the absolute frequencies of student science teachers' views on NOS. All of them were familiar with NOS issues, such as those that support that science needs creativity and imagination. These student teachers could extensively mention the different stages of the scientific method in which creativity and imagination is required. Most of them gave particular emphasis to the phase of designing the experimental apparatus.

The idea that science is tentative is very popular among students (21 out of 23), in the sense that scientific theories are subject to change in the light of new evidence. They could give examples of scientific theories, such as Newton's Theory of Classic Mechanics that was replaced by Einstein's Special Theory of Relativity to include a wider range of phenomena.

Regarding the social and cultural influence on science, most student teachers (18 out of 23) could formulate either historical or modern examples in which the social and political influence on science is depicted. Most student teachers were focused on the modern relationship between science and the global market, and argued that research interests are defined by the financial interests. For example, the future of telecommunications is strongly related to its effects on human kind. Only three of the students could support cultural influence on science in a historical context and particularly by referring to Galileo's renunciation by the Inquisition. The minority of students (5 out of 23) claimed that science used to be influenced by cultural milieu but today this is not the case. They expressed the view that nowadays scientific research is being carried out in absolute objectivity, in the sense that neither church nor political interests control the scientific community.

The distinction between observation and inference and the fact that scientific knowledge is theory laden was less evident among student teachers. Specifically, 14 out of 23 students could recognize not only the role of data but also the role of reasoning in theory production. Also, they realized that scientists' theoretical commitments and previous knowledge actually influence their work. Some students provided arguments such as although scientists may have the same set of data, they do not perceive them in the same way, implying that there is no neutral observation. The minority of students, 9 out of 23, had more naïve views on the topic, expressing views that there can't be two different theories for the same set of data. 


\section{Macrothink}

The aspect of NOS that students had the biggest difficulty with was the distinction between laws and theories. The majority of them, 15 out of 23, expressed views which supported that laws are certain and unchangeable, while theories are subject to change, in the sense that they are not experimentally proved and if a theory is experimentally proved, then it becomes a law. The minority of them, only 8 out of 23 , could support the view that theories and laws have different functions and that laws describe mathematically the phenomena while theories explain them.

Table 2. Absolute frequencies of student science teachers' views on NOS

\begin{tabular}{|c|c|c|}
\hline NOS aspect & $\begin{array}{l}\text { Informed } \\
\text { (Frequency) }\end{array}$ & $\begin{array}{l}\text { Naïve } \\
\text { (Frequency) }\end{array}$ \\
\hline Theories and Laws (VNOS C - Q5) & 8 & 15 \\
\hline Tentative (VNOS C - Q4) & 21 & 2 \\
\hline $\begin{array}{l}\text { Creative and Imaginative (VNOS C - } \\
\text { Q10) }\end{array}$ & 23 & - \\
\hline $\begin{array}{l}\text { Subjective and theory laden - } \\
\text { Distinction between observation and } \\
\text { inference (VNOS C - Q8) }\end{array}$ & 14 & 9 \\
\hline Social and Cultural (VNOS C - Q9) & 18 & 5 \\
\hline
\end{tabular}

\subsection{Student Science Teachers’Attitude towards NOS Teaching in Schools}

In order to collect science teachers' stances towards NOS teaching and learning, they were asked to complete a questionnaire (Souter \& Findlay, 2008; McComas et al., 1998). Students answered for every aspect of NOS their opinion about the importance of the particular aspect to be taught and if they had included it in their teaching scenarios. In Table 3 the absolute frequency for every one of the 14 aspects of NOS along with the corresponding information coming from the observations are provided. The last column provides the number of student teachers who have included the corresponding aspect of NOS in their teaching scenarios, according to observations during the presentations. 


\section{Ml Macrothink}

Table 3. Student teachers' attitude towards NOS teaching and learning in school

\begin{tabular}{|c|c|c|c|c|c|c|c|c|c|}
\hline 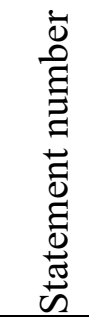 & 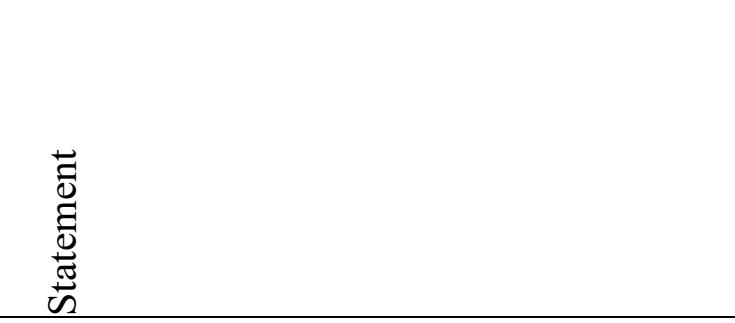 & 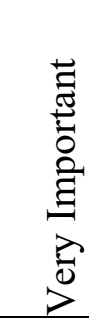 & 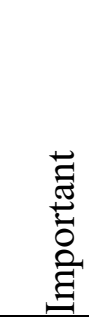 & 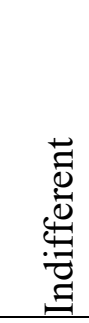 & 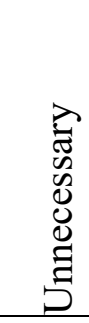 & $\stackrel{\infty}{\infty}$ & 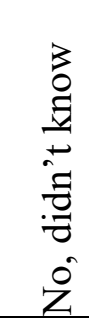 & 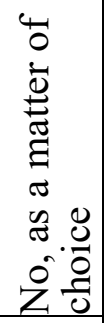 & 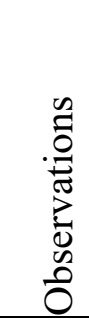 \\
\hline$Q^{\prime}{ }_{1}$ & $\begin{array}{l}\text { Science is an attempt to explain natural } \\
\text { phenomena. }\end{array}$ & 20 & 3 & & & 16 & - & 7 & 14 \\
\hline$Q^{\prime}{ }_{2}$ & $\begin{array}{l}\text { Scientific knowledge is durable, but } \\
\text { tentative. }\end{array}$ & 10 & 10 & 2 & 1 & 10 & 6 & 7 & 6 \\
\hline$Q^{\prime}{ }_{3}$ & $\begin{array}{l}\text { Scientific knowledge relies heavily on } \\
\text { observation, experimental evidence, } \\
\text { rational arguments and skepticism. }\end{array}$ & 16 & 5 & 1 & 1 & 14 & 5 & 4 & 12 \\
\hline$Q^{\prime}{ }_{4}$ & $\begin{array}{l}\text { Laws and theories have different roles in } \\
\text { science. }\end{array}$ & - & 13 & 7 & 3 & 9 & 10 & 4 & - \\
\hline$Q^{\prime}{ }_{5}$ & $\begin{array}{l}\text { New knowledge must be reported clearly } \\
\text { and openly. }\end{array}$ & 10 & 11 & 1 & 1 & 8 & 10 & 5 & - \\
\hline$Q^{\prime}{ }_{6}$ & $\begin{array}{l}\text { Scientists require accurate recordkeeping, } \\
\text { peer review and replicability }\end{array}$ & 14 & 6 & 1 & 2 & 15 & 4 & 4 & - \\
\hline$Q^{\prime} 7$ & Observations are theory-laden. & 5 & 9 & 4 & 5 & 5 & 10 & 8 & 5 \\
\hline$Q^{\prime}{ }_{8}$ & There is no one way to do science. & 6 & 11 & 5 & 1 & 8 & 10 & 5 & 5 \\
\hline Q’9 & $\begin{array}{l}\text { People from all cultures contribute to } \\
\text { science. }\end{array}$ & 16 & 4 & 2 & 1 & 8 & 9 & 6 & 4 \\
\hline$Q^{\prime} 10$ & Scientists are creative. & 12 & 7 & 2 & 2 & 10 & 5 & 8 & 4 \\
\hline$Q^{\prime} 11$ & $\begin{array}{l}\text { The history of science reveals both an } \\
\text { evolutionary and a revolutionary character. }\end{array}$ & 8 & 8 & 6 & 1 & 12 & 7 & 4 & 5 \\
\hline$Q^{\prime}{ }_{12}$ & $\begin{array}{l}\text { Science is part of social and cultural } \\
\text { traditions. }\end{array}$ & 4 & 9 & 6 & 4 & 8 & 6 & 9 & 2 \\
\hline$Q^{\prime} 13$ & Science and technology impact each other. & 13 & 10 & - & - & 13 & 6 & 4 & 10 \\
\hline$Q^{\prime}{ }_{14}$ & $\begin{array}{l}\text { Scientific ideas are affected by the social } \\
\text { and historical milieu. }\end{array}$ & 8 & 10 & 3 & 2 & 8 & 6 & 9 & 3 \\
\hline
\end{tabular}

Among the fourteen aspects of NOS, student teachers considered the following as very important to be taught in the context of school science: the fact that science is an attempt to explain natural phenomena (20 out of 23 students), the fact that scientific knowledge relies heavily on observation, experimental evidence, rational arguments and skepticism (16 out of 23 students), the fact that people from all cultures contribute to science (16 out of 23 students) and the fact that scientists require accurate recordkeeping, peer review and replicability (14 out 
of 23 students). More than half (13 out of 23 students) recognized that science and technology impact each other.

It is evident from Table 3 that the more epistemological aspects of NOS are not recognized by student teachers as very important in the context of school science. For example, none of the student teachers found the distinction between laws and theories very important, while a limited number of them ( 5 out of 23 ) assess the fact that observations are theory laden to be very important. Only 6 out of 23 found the fact that there is more than one way to do science very important for school science. Regarding NOS aspects related to sociocultural influence on science, most student teachers did not consider them very important to be included in school science. For example, the idea that science is part of the social and cultural tradition was evaluated as very important only by 4 out of 23 students.

As far as the relation between student teachers' stances towards teaching NOS and their proposed teaching scenarios are concerned, there seems to be a moderate correlation. The aspects of NOS that were assessed as very important were, in most cases, introduced in their teaching scenarios. For example, 20 out of 23 student teachers supported that the view "science is an attempt to explain natural phenomena" is very important and should be explicitly taught in the context of school science. What is more, 16 of them claimed to have included this aspect in their scenario and 14 of them had actually done it, according to the observation results during the presentation. However, not all the "very important" aspects were introduced in teaching proposals. For example, students had difficulties in connecting their opinion that "people from all cultures contribute to science" is very important to be taught in school science with their teaching proposal. Only 4 out of the 16 participants who supported this aspect as very important managed to suggest activities through which this aspect is taught.

Table 3 also reveals another finding. Specifically, several student teachers claim that they have included in their teaching proposals some aspects of the NOS without having done them in practice, despite being expected to do so and take into account the observations during student teachers' presentations. Such a finding leads us to conclude that it is either difficult for student teachers to apply the theory of didactics of science or to conceptualize several aspects of NOS.

The first possibility has to do with whether or not students have understood the basic principles of didactics: how an objective should be set and achieved through certain activities. This turns out to be more difficult when it comes to NOS teaching, where teaching activities are difficult to integrate into teaching plans, especially for inexperienced teachers. However, we have some evidence that regarding the epistemological aspects, student teachers have conceptual difficulties that are revealed by the open-ended answers (VNOS-C). For example, regarding the distinction between theories and laws; only 8 out of 23 have stated views on the topic, none of them finds the particular aspect of NOS very important, 9 of them claim that they included that aspect in their teaching objectives and, finally, no one actually did include this idea in their presentations. What is implied is that student teachers haven't understood the meaning of the aspect under question namely "the difference between theories and laws", and gave unreliable answers. For all the reasons mentioned above, we produce some first findings about the relation between student teachers' views on NOS and their attitude towards NOS based on 
students' opinions and not their practices.

4.3 The relation between student teachers' views on NOS and their attitudes towards NOS teaching.

At this point, we will try to relate the student teachers' views on NOS with their attitudes towards teaching NOS in the context of school science. In Table 4, we present both students' views on the five aspects of NOS (according to Table 2) and their attitudes towards teaching NOS. For every one of the five NOS aspects of the first column, we have noted the corresponding questions of the third questionnaire (Table 3). For example, regarding "theories and laws" aspect, the analysis of VNOS-C revealed that 8 out of 23 participants have an informed view regarding the role of theories and laws; the analysis of the second questionnaire (Table 3) revealed that although none of them finds this aspect very important, 9 of them claim that they have included this particular aspect in their teaching scenarios and, finally, the observations revealed that none of them have done it in practice (last column).

As has already been discussed in the previous section, Table 4, along with Table 3, reveal that the majority of student teachers claim that they have included a particular aspect of NOS in their teaching scenarios while indeed they have not. For the reasons previously mentioned, we present the data of the observations during students' presentations but the analysis is based on their answers in the questionnaires.

It seems that there is a relation between student teachers' knowledge about NOS aspects and their attitudes towards teaching this particular aspect, provided that we focus on students teachers' opinions as being very important and their claim about whether they included this particular aspect in their teaching scenario or not.

For example, speaking about the "Creative and imaginative character of science", which was the best understood concept among participants ( 23 out of 23 have an informed view), the analysis of data reveal that it is the most popular aspect of NOS regarding teaching school science ( 12 out of 23 find it very important, 10 out of 23 claim that they have included it in their scenarios and 4 of them have indeed included it). The "Tentative character of science" which is a very understandable NOS aspect too (21 out of 23 students have an informed view), has a high number of supporters, regarding teaching school science (10 out of 23 find it very important, 10 out of 23 claim that they have included it in their scenarios and 6 of them have indeed included it). If we focus on an NOS aspect that is comparatively less understood, such as that "Scientific knowledge is subjective and theory laden" (only 14 students have an informed view), we observe that only 5 out of 23 students find it important and claim to teach something relevant through their teaching scenarios. 


\section{Macrothink}

Table 4. Relation between student teachers' views on NOS and their attitude towards NOS teaching

\begin{tabular}{|c|c|c|c|c|c|c|c|c|c|c|}
\hline 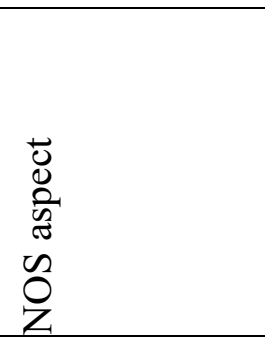 & 己ृّ & $: \stackrel{0}{:}$ & $\begin{array}{l}\vec{\Xi} \\
\stackrel{\Xi}{0} \\
\stackrel{0}{0} \\
. \Xi \\
\stackrel{0}{0}\end{array}$ & 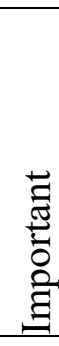 & 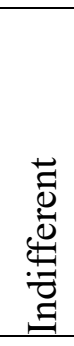 & 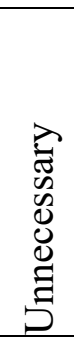 & $\stackrel{\theta}{\otimes}$ & 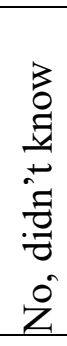 & 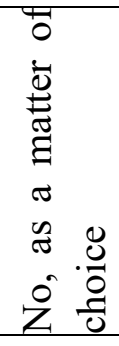 & $\begin{array}{l}\text { 0 } \\
.0 \\
0 \\
0 \\
0 \\
0 \\
0 \\
0\end{array}$ \\
\hline $\begin{array}{l}\text { Theories and } \\
\text { Laws }\left(Q^{\prime}{ }_{4}\right)\end{array}$ & 8 & 15 & - & 13 & 7 & 3 & 9 & 10 & 4 & - \\
\hline Tentative ( $\left.\mathrm{Q}_{2}{ }_{2}\right)$ & 21 & 2 & 10 & 10 & 2 & 1 & 10 & 6 & 7 & 6 \\
\hline $\begin{array}{l}\text { Creative and } \\
\text { Imaginative } \\
\left(Q^{\prime}{ }_{10}\right)\end{array}$ & 23 & - & 12 & 7 & 2 & 2 & 10 & 5 & 8 & 4 \\
\hline $\begin{array}{l}\text { Subjective and } \\
\text { Theory laden - } \\
\text { Distinction } \\
\text { between } \\
\text { observation } \\
\text { and inference } \\
\left(Q^{\prime}{ }_{7}\right)\end{array}$ & 14 & 9 & 5 & 9 & 4 & 5 & 5 & 10 & 8 & 5 \\
\hline $\begin{array}{l}\text { Social and } \\
\left.\text { Cultural (Q' }{ }_{14}\right)\end{array}$ & 18 & 5 & 8 & 10 & 3 & 2 & 8 & 6 & 9 & 3 \\
\hline
\end{tabular}

Preliminary findings show that in our sample there has been a relatively high relationship between students' views on NOS and their stance towards teaching NOS, particularly regarding specific NOS "tenets" such as the tentativeness and creativity in science. On the contrary, in respect of deeper epistemological aspects, such as hypothesis, laws and theories in which student teachers had more naive views, they do not suggest them as important nor do they include them in the teaching material they develop.

\section{Conclusion - Discussion}

The purpose of this article was to investigate the relation between student science teachers' views on NOS and their stance towards teaching NOS. The research has the character of a case study. The main limitation of the study is the limited number of the participants and the fact that the participants were acquired through a convenient sample and not a sample with special characteristics. Hence, the findings cannot be generalizable. They can only be discussed in terms of their implications for further research. The student teachers participants 
of the study, had fully attended a course, called Didactics of Science, in the context of which they focused on issues related to scientific literacy and how to teach science, including concepts, procedures and NOS. No particular emphasis was given to NOS teaching and learning.

The findings show a moderate relation between student teachers' views on NOS issues and their interest and intention to teach them. Regarding issues such as the tentativeness and creativity of science, the majority of students have informed views and those of them who appreciate these NOS aspects as very important, propose them for teaching in the context (curriculum) of school science. When it comes to more epistemological issues, such as the difference between a theory and a law, then student teachers have more naive views and they also find it less important for a school science context.

This research, with its exploratory character, can provide the basis for larger scale research to explore in depth whether and in what extent student science teachers' positive stance towards teaching NOS in their classrooms may be reinforced by their own in-depth deep knowledge of the subject.

Finally, the difference between how many student teachers propose an issue as very important to be taught and how many of them ultimately teach it (according to the remarks made during their presentations) shows that future teachers have difficulty in teaching NOS issues in their classes, even if they have decided to do so. Therefore, what is proposed is the inclusion into the corresponding undergraduate science curricula of courses focusing on NOS issues and their engagement in teaching practice, as a necessary component of didactics of science.

\section{References}

Abd-El-Khalick, F. \& Lederman, N. G. (2000). The influence of history of science courses on students' views of nature of science. Journal of Research in Science Teaching, 37(10), 1057-1095. https://doi.org/10.1002/1098-2736(200012)37:10<1057::AID-TEA3>3.0.CO;2-C

Allchin, D. (2011). Evaluating knowledge of the Nature of (Whole) Science. Science Education, 95(3), 693-700. https://doi.org/10.1002/sce.20432

American Association for the Advancement of Science. (1993, 2009). Benchmarks Online. Retrieved from http://www.project2061.org/publications/bsl/online/index.php.

American Association for the Advancement of Science. (2013). Science for all Americans. Retrieved from http://www.project2061.org/publications/sfaa.

Anderson, K.E. (1950). The teachers of science in a representative sampling of Minnesota schools. Science Education, 34, 57-66. https://doi.org/10.1002/sce.3730340114

Carey, R. L. \& Strauss, N. (1968). An analysis of the understanding of the nature of science by prospective secondary science teachers. School Science and Mathematics, 70, 366-376. https://doi.org/10.1002/sce.3730520410

Cawthorn, E.R \& Rowell, J. A. (1978). Epistemology and science education. Studies in Science Education, 5, 31-57. https://doi.org/10.1080/03057267808559856 
DeBoer, G. (1991). A History of Ideas in Science Education: Implications for Practice. Columbia University, New York, NY: Teachers College.

Duschl, R. A. \& Grandy, R. (2013). Two views about explicitly teaching Nature of Science. Science \& Education, 22, 2109-2139. https://doi.org/10.1007/s11191-012-9539-4

Hipkins, R., Barker, M. \& Bolstad, R. (2005). Teaching the 'nature of science': modest adaptations or radical reconceptions? International Journal of Science Education, 27(2), 243-254. https://doi.org/10.1080/0950069042000276758

Hodson, D. (2014). Nature of science in the science curriculum: origin, development, implications and shifting emphases. In M. R. Matthews (Ed.), International handbook of research in history, philosophy and science teaching (pp. 911-970). Dordrecht, The Netherlands: Springer. https://doi.org/10.1007/978-94-007-7654-8_28

Irzik, G. \& Nola, R. (2011). A family resemblance approach to the nature of science for science education. Science \& Education, 20(7-8), 591-607. https://doi.org/10.1007/s11191-010-9293-4

Kampourakis, K. (2016). The "general aspects" conceptualization as a pragmatic and effective means to introducing students to nature of science. Journal of Research in Science Teaching, 53(5), 667-682. https://doi.org/10.1002/tea.21305

Lederman, N. G. (1992). Students' and teachers' conceptions of the nature of science: A review of the research. Journal of Research in Science Teaching, 29(4), 331-359. https://doi.org/10.1002/tea.3660290404

Lederman, N. G. (1999), Teachers' understanding of the nature of science and classroom practice: Factors that facilitate or impede the relationship. Journal of Research in Science Teaching, 36 , 916-929. https://doi.org/10.1002/(SICI)1098-2736(199910)36:8<916::AID-TEA2>3.0.CO;2-A

Lederman, N. G., Abd-El-Khalick, F., Bell, R. L. and Schwartz, R. S. (2002). Views of nature of science questionnaire: Toward valid and meaningful assessment of learners' conceptions of nature of science. Journal of Research in Science Teaching, 39, 497-521. https://doi.org/10.1002/tea.10034

Lederman, N. (2006). Nature of Science: Past, Present and Future. In S. Abell and N. Lederman (Ed.), Handbook of Research on Science Education (pp. 831-880). New Jersey, NJ: Lawrence Erlbaum Associate.

Matthews, M. R. (2012). Changing the focus: From nature of science (NOS) to features of science (FOS). In M. S. Khine (Ed.), Advances in nature of science research: Concepts and methodologies (pp. 3-26). Dordrecht, The Netherlands: Springer. https://doi.org/10.1007/978-94-007-2457-0_1

McComas, W. F., Clough, M. P., \& Almazroa, H. (1998). The role and character of the nature of science in science education. In W. F. McComas (Ed.), The Nature of Science in Science Education: Rationales and Strategies. (Vol. 5). Dordrecht: Kluwer Academic Press. 
Millar, R. \& Osborne, J. (1998). Beyond 2000: Science Education for the Future. London, London: King's College.

Miller, P.E. (1963). A comparison of the abilities of secondary teachers and students of biology to understand science. Iowa Academy of Science, 70, 510-513.

NGSS Lead States. (2013). Next generation science standards: For states, by states. Washington, DC: The National Academies Press.

Niaz, M. (2009). Progressive transitions in chemistry teachers' understanding of nature of science based on historical controversies. Science \& Education, 18, 43 - 65. https://doi.org/10.1007/s11191-007-9082-x

National Science Teachers Association (NSTA). (2000). Beyond 2000 - Science teachers speak out. Retrieved from http://www.nsta.org/about/positions/beyond2000.aspx

Organization for the Economic Cooperation and Development (OECD). (2009). The PISA 2003 assessment framework - mathematics, reading, science and problem solving knowledge and skills. Retrieved from http://www.oecd.org/pisa/pisaproducts/pisa2003/pisa2003assessmentframeworkmathematicsr eadingscienceandproblemsolvingknowledgeandskills-publications2003.htm .

Osborne, J., Collins, S., Ratcliffe, M., Millar, R. \& Duschl, R. (2003). What "ideas-about-science" should be taught in school science? A Delphi study of the expert community. Journal of Research in Science Teaching, 40 (7), 692-720. https://doi.org/10.1002/tea.10105

Rowell, J.A. \& Cawthron, E.R (1982). Images of Science: an Empirical Study. European Journal of Science Education, 4(1), 79-94. https://doi.org/10.1080/0140528820040109

Souter, N. \& Findlay, M. (2008). Student Teachers Views on the Nature of Science. Paper presented in British Educational Research Association Conference (BERA) 2008, Heriot-Watt University, Edinburgh, 3-6 September 2008.

Stefanidou, C. \& Skordoulis, C. (2017). Primary Students Teachers' Understanding of Basic Ideas of Nature of Science: Laws, Theories and Models. Journal of Studies in Education, 7, 127-153. https://doi.org/10.5296/jse.v7i1.10599

Stefanidou, C \&. Skordoulis, C. (2014). Subjectivity and Objectivity in Science: An Educational Approach. Advances in Historical Studies, 3, 183-193. https://doi.org/10.4236/ahs.2014.34016

Stefanopoulou, S. \& Kechagias, C.Th. (2018). Improving the educational practice using simulations in science education: The contribution of Althusser's theory on the cognitive procedure. European Journal of Education Studies, 4(3), 61-78.

\section{Appendix - Views on Nature of Science (VNOS C) (Lederman et al., 2002)}

$\mathrm{Q}_{1}$. What, in your view, is science? What makes science (or a scientific discipline such as physics, biology, etc.) different from other disciplines of inquiry (e.g., religion, philosophy)? 
Q2. What is an experiment?

Q3. Does the development of scientific knowledge require experiments?

If yes, explain why. Give an example to defend your position.

If no, explain why. Give an example to defend your position.

Q4. Science textbooks often represent the atom as a central nucleus composed of protons (positively charged particles) and neutrons (neutral particles) with electrons (negatively charged particles) orbiting that nucleus. How certain are scientists about the structure of the atom? What specific evidence, or types of evidence, do you think scientists used to determine what an atom looks like?

$\mathrm{Q}_{5}$. Is there a difference between a scientific theory and a scientific law? Illustrate your answer with an example.

Q6. After scientists have developed a scientific theory (e.g., atomic theory, evolution theory) does the theory ever change?

If you believe that scientific theories do not change, explain why. Defend your answer with examples.

If you believe that scientific theories do change:

(a) Explain why theories change?

(b) Explain why we bother to learn scientific theories. Defend your answer with examples.

Q7. Science textbooks often define a species as a group of organisms that share similar characteristics and can interbreed with one another to produce fertile offspring. How certain are scientists about their characterization of what a species is? What specific evidence do you think scientists used to determine what a species is?

Q8. Scientists perform experiments/investigations when trying to find answers to the questions they put forth. Do scientists use their creativity and imagination during their investigations?

If yes, then at which stages of the investigations do you believe that scientists use their imagination and creativity: planning and design; data collection; after data collection? Please explain why scientists use imagination and creativity. Provide examples if appropriate.

If you believe that scientists do not use imagination and creativity, please explain why. Provide examples if appropriate.

Q9. It is believed that about 65 million years ago the dinosaurs became extinct. Of the hypotheses formulated by scientists to explain the extinction, two enjoy wide support. The first, formulated by one group of scientists, suggests that a huge meteorite hit the earth 65 million years ago and led to a series of events that caused the extinction. The second hypothesis, formulated by another group of scientists, suggests that massive and violent volcanic eruptions were responsible for the extinction. How are these different conclusions possible if scientists in both groups have access to and use the same set of data to derive their conclusions?

$\mathrm{Q}_{10}$. Some claim that science is infused with social and cultural values. That is, science 


\section{Macrothink}

reflects the social and political values, philosophical assumptions, and intellectual norms of the culture in which it is practiced. Others claim that science is universal. That is, science transcends national and cultural boundaries and is not affected by social, political, and philosophical values, and intellectual norms of the culture in which it is practiced.

If you believe that science reflects social and cultural values, explain why and how. Defend your answer with examples.

If you believe that science is universal, explain why and how. Defend your answer with examples.

\section{Copyright Disclaimer}

Copyright for this article is retained by the author(s), with first publication rights granted to the journal.

This is an open-access article distributed under the terms and conditions of the Creative Commons Attribution license (http://creativecommons.org/licenses/by/3.0/). 